\title{
Stock Price Reactions To Debt Initial Public Offering Announcements
}

Kelly Cai, University of Michigan - Dearborn, USA

Heiwai Lee, University of Michigan - Dearborn, USA

\begin{abstract}
We examine the valuation effect of initial public debt offers on issuing firms' common stock for the period 1970 to 2010. In contrast to findings for seasoned debt offerings, we find a statistically significant cumulative abnormal return of -0.24 percent over the three-day announcement period for the overall sample of 1,207 debt IPOs. Consistent with the prediction of the adverse selection model of Myers and Majluf (1984), the significant negative valuation effect of debt IPOs is only associated with risky issues that are assigned a high-yield bond rating. The announcements of low-risk investment grade debt IPO issues are associated with insignificant positive stock price reaction. In addition to the certifying effect of investment grade rating, the market also reacts favorably to successful debt IPOs issued under challenging conditions.
\end{abstract}

Keywords: Debt Initial Public Offer \& Stock Prices; Debt IPO \& Stock Valuation

\section{INTRODUCTION}

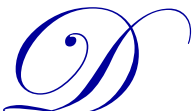

ebt initial public offerings (Debt IPOs) represent a major shift in a firm's financing policy. It offers the issuing firms access to the enormous public debt market which provides a major funding source for these firms to finance their operations and investments. According to Thomson Financial's Securities Data Corporation's (SDC) New Issue database, both the aggregate amount and issue size of public debt offerings are larger than those of public equity offerings. However, when compared to the volume of research on equity offerings, there is relatively limited research on the valuation effect of debt IPO on issuing firms' stock prices. Most research examines seasoned debt offering and documents an insignificant negative risk-adjusted stock return at the announcement period ${ }^{1}$.

Debt IPOs are different from the seasoned offers. A debt IPO could transform a firm's capital structure as it not only provides the issuer access to the enormous public debt market, it also alters the issuing firm's public and private debt composition. In addition, a debt IPO could impact the information environment as it subjects the issuing firm to the review of bond rating agencies and the associated certification effect (Hale and Santos, 2008). In contrast to findings for seasoned debt offerings, by using a sample of 143 debt IPOs offered from 1971 to 1994, Datta et al (2000) find a significantly negative stock price response to debt IPOs announcements.

Our study contributes to the literature on debt financing by examining stock price reactions with a comprehensive sample of initial public offerings of straight debt by U.S. nonfinancial corporations over an extended sample period of 1970 2010. We also examine the impact of debt's credit rating and overall economy environment on the debt IPO's announcement period abnormal return.

Miller and Rock (1985) argue that external financing signals earnings shortfall of the issuing firm. Hence, they predict that all forms of external financing, including public debt, will have a negative valuation effect on stock returns, despite the riskiness of the security being issued. On the other hand, the adverse selection argument of

\footnotetext{
${ }^{1}$ For example, Smith (1986) finds the average stock price reaction to the announcement of seasoned straight debt offers is -0.26 percent and is not statistically significant. Shyam-Sunder (1991) also finds that announcements of seasoned straight debt offerings are not associated with a significant stock price reaction.
}

(C) 2013 The Clute Institute http://www.cluteinstitute.com/ 
Myers and Majluf (1984) suggests that the valuation effect of external financing decision depends on the riskiness of the security being issued. In specific, the riskier the security, the more negative is the valuation effect. According to Myers and Majluf, the valuation effect of equity offerings would be most negative while that for safe debt offerings would be least negative or even positive. Empirical findings on the valuation effects of seasoned security offerings summarized in Eckbo et al. (2007) are consistent with the adverse selection argument. In general, equity offering announcements experience most significant negative stock price reactions, while straight debt offering announcements experience insignificant market reactions ${ }^{2}$.

Further implication of the adverse selection argument suggests a possible role of bond ratings on the valuation effect of debt IPO announcement. Since bond ratings reflect the credit riskiness of the issue, Myers and Majluf (1984) predicts less (or more) negative stock price reactions to investment (or speculative) grade debt IPOs. On the other hand, Miller and Rock (1985) would suggest no difference in the valuation effect of debt IPOs regardless of their bond ratings ${ }^{3}$. In this study, we contribute further evidence on the possible role of bond ratings on stock price reactions to financing decisions with debt IPOs.

Bernanke and Gertler (1989) show that the information problem faced by financially strained firms become more severe during economic downturns that could prohibit them from raising external capital. Hence, a successful debt IPO issued during economic recession may favorably reflect the quality of the issuing firm. Consistent with this postulation, Jilio et al. (2008) report that, when compared to normal economic environment, there are fewer highyield bonds but a similar number of investment grade bonds successfully issued during economic recessions in their comprehensive study of seasoned debt offerings. We further examine this postulation with an emphasis on stock price reactions to debt IPO announcements under different economic conditions.

Based on a comprehensive sample of 1,207 debt initial public offers spanning forty-one years from 1970 to 2010, we find statistically significant negative stock price reactions to the debt IPO announcements. The three-day cumulative abnormal return is -0.24 percent. This result contrasts the insignificant valuation effect of seasoned debt offers summarized in Eckbo et al. (2007), but is consistent with the finding of Datta et al. (2000) on a small sample of debt IPOs.

In further analysis, we find that there is statistically significant difference between the valuation effects of investment grade (IG) and high-yield (HY) bonds on stock returns of issuing firms. IG debt IPOs experience a positive cumulative abnormal return of 0.15 percent. In contrast, HY debt IPO announcements are associated with a statistically significant negative cumulative abnormal return of -0.52 percent. These results are consistent with Myers and Majluf (1984) that announcement of safer (investment grade) debt offering will have no or positive stock price reaction; however, and announcement of risky (high-yield) debt offering may cause stock prices of issuing firms to decline.

Our further analysis also suggests a possible role of economic condition on the distribution of debt IPOs and stock price reactions to debt IPO announcements. Consistent with Julio et al. (2008), there is a higher percentage of IG debt IPOs issued during economic downturns. We also observe that debt IPOs of both HY and IG issues experience positive cumulative abnormal returns in the recession period. This finding is consistent with the implication of Bernanke and Gertler (1989) that the market recognizes and rewards quality issuers who successfully conduct debt IPOs even during challenging economic times.

In Section 2, we discuss the data and sample used. Section 3 documents the methodology. Section 4 reports the empirical results and Section 5 concludes the study.

\footnotetext{
2 The insignificant stock price reactions associated with seasoned straight debt offerings could be, however, partially explained by the possible market anticipation of such event. Eckbo et al. (2007) reports mixed evidences for the partial anticipation explanation for the valuation effect of seasoned debt offerings.

${ }^{3}$ Consistent with Miller and Rock (1985), Shyam-Sunder (1991) does not find a statistically significant bond rating effect on the valuation effect of seasoned debt offerings. 


\section{SAMPLE SELECTION AND DESCRIPTION}

We first identify the very first public straight debt offer of nonfinancial U.S. firms reported in the SDC New Issues database. This yields an initial sample of 3,180 potential debt IPOs issued between 1970 and 2010. Since the SDC database started its coverage in 1970, some issuers in our initial sample might have public debt offerings prior to 1970 and hence do not meet the definition of debt IPO, i.e., the very first public offering of debt by the issuing firm. Hence, we apply further screening for debt IPOs by examining the founding date of each sample firm and exclude firms that were founded prior to $1970^{4}$ as they might have issued public debt prior to our sample period $^{5}$. Next, we obtain stock prices and returns from the Center for Research in Security Prices (CRSP) database and delete firms with insufficient data. Our final sample includes 1,377 debt IPOs issued by 1,207 public firms.

Table 1. Debt IPOs by Issue Year

\begin{tabular}{|c|c|c|c|c|c|c|c|}
\hline $\begin{array}{l}\text { Year of } \\
\text { Issue }\end{array}$ & Number & Proportion & $\begin{array}{c}\text { Average Issue } \\
\text { Size }\end{array}$ & $\begin{array}{l}\text { Year of } \\
\text { Issue }\end{array}$ & Number & Proportion & $\begin{array}{c}\text { Average } \\
\text { Issue Size }\end{array}$ \\
\hline 1970 & 84 & $6.96 \%$ & 302.92 & 1991 & 22 & $1.82 \%$ & 135.29 \\
\hline 1971 & 64 & $5.30 \%$ & 296.18 & 1992 & 35 & $2.90 \%$ & 274.73 \\
\hline 1972 & 21 & $1.74 \%$ & 156.97 & 1993 & 51 & $4.23 \%$ & 179.78 \\
\hline 1973 & 7 & $0.58 \%$ & 104.73 & 1994 & 38 & $3.15 \%$ & 230.37 \\
\hline 1974 & 22 & $1.82 \%$ & 536.26 & 1995 & 40 & $3.31 \%$ & 312.13 \\
\hline 1975 & 50 & $4.14 \%$ & 398.08 & 1996 & 38 & $3.15 \%$ & 201.43 \\
\hline 1976 & 22 & $1.82 \%$ & 161.60 & 1997 & 35 & $2.90 \%$ & 613.05 \\
\hline 1977 & 37 & $3.07 \%$ & 150.50 & 1998 & 29 & $2.40 \%$ & 250.14 \\
\hline 1978 & 43 & $3.56 \%$ & 77.78 & 1999 & 19 & $1.57 \%$ & 815.17 \\
\hline 1979 & 31 & $2.57 \%$ & 328.45 & 2000 & 8 & $0.66 \%$ & 424.69 \\
\hline 1980 & 38 & $3.15 \%$ & 189.51 & 2001 & 18 & $1.49 \%$ & 1101.51 \\
\hline 1981 & 16 & $1.33 \%$ & 130.91 & 2002 & 13 & $1.08 \%$ & 262.11 \\
\hline 1982 & 28 & $2.32 \%$ & 96.63 & 2003 & 8 & $0.66 \%$ & 498.38 \\
\hline 1983 & 42 & $3.48 \%$ & 120.66 & 2004 & 6 & $0.50 \%$ & 195.85 \\
\hline 1984 & 35 & $2.90 \%$ & 153.83 & 2005 & 7 & $0.58 \%$ & 537.58 \\
\hline 1985 & 68 & $5.63 \%$ & 200.03 & 2006 & 16 & $1.33 \%$ & 1758.36 \\
\hline 1986 & 64 & $5.30 \%$ & 178.85 & 2007 & 14 & $1.16 \%$ & 1185.94 \\
\hline 1987 & 35 & $2.90 \%$ & 297.83 & 2008 & 13 & $1.08 \%$ & 713.76 \\
\hline 1988 & 21 & $1.74 \%$ & 248.71 & 2009 & 21 & $1.74 \%$ & 1250.81 \\
\hline 1989 & 11 & $0.91 \%$ & 221.41 & 2010 & 28 & $2.32 \%$ & 859.17 \\
\hline 1990 & 9 & $0.75 \%$ & 217.49 & Total & 1,207 & $100 \%$ & 335.60 \\
\hline
\end{tabular}

Table 1 reports the number, proportion and average issue size of the debt IPOs sample ${ }^{6}$. We note extensive variations in debt IPO activities over the sample period. For instance, the number of debt IPOs issues ranges from a low of 6 in 2004 to a high of 84 in 1970. The average issue size of debt IPO is $\$ 335.6$ million in constant year 2000 dollars.

Table 2 reports descriptive statistics of the debt IPOs sample. Panel A indicates that there is one unrated debt IPO for every four rated debt IPOs at the time of their issuance. There is an even split between IG (41\%) and HY $(38 \%)$ among rated debt IPOs, with B-rated bonds being the largest group that accounts for $26 \%$ of the sample.

Consistent with Datta, et al. (2000) that public debt tends to have longer maturity than bank loans, Panel B reports that $44 \%$ of our debt IPOs have a maturity of 10 years or longer, about half has a maturity between 5 to 10 years, and only $6 \%$ has a maturity of 5 years or shorter ${ }^{7}$. The average (median) maturity of initial public debt is about fourteen (ten) years. The issuance of public debt does lengthen the debt maturity structure of the issuing firms. Panel C reports that over half $(58 \%)$ of the debt IPOs are issued by firms that have been public for more than ten years. The issuing firms wait for an average (median) of eighteen (fourteen) years after going public before their very first public debt offer.

\footnotetext{
${ }^{4}$ We thank Jay Ritter and Laura Field for providing the founding dates for equity IPOs downloadable from Jay Ritter's website.

${ }^{5}$ As a robustness check, we replicate our analysis including these firms and obtain similar results.

${ }^{6}$ For firms that issue multiple debts on the same day, we use the total proceeds of these multiple-issue debt IPOs.

${ }^{7}$ For firms that issue multiple debts on the same day, we compute their weighted average maturity.
} 
Table 2. Frequency Distribution of Debt IPOs

\begin{tabular}{|c|c|c|}
\hline Descriptive Variable & \# of Debt IPOs & Percentage \\
\hline \multicolumn{3}{|c|}{ Panel A: Frequency Distribution of Debt IPOs by Standard \& Poor's Bond Ratings } \\
\hline AAA & 26 & $2.15 \%$ \\
\hline AA & 64 & $5.30 \%$ \\
\hline A & 194 & $16.07 \%$ \\
\hline BBB & 217 & $17.98 \%$ \\
\hline $\mathrm{BB}$ & 118 & $9.78 \%$ \\
\hline B & 313 & $25.93 \%$ \\
\hline $\mathrm{CCC}$ & 25 & $2.07 \%$ \\
\hline NR & 250 & $20.71 \%$ \\
\hline Investment Grade (IG) & 501 & $41.51 \%$ \\
\hline High Yield Grade (HY) & 456 & $37.78 \%$ \\
\hline NR & 250 & $20.71 \%$ \\
\hline \multicolumn{3}{|c|}{ Panel B: Frequency Distribution of Debt IPOs by Maturity (in Years) } \\
\hline $0<$ Maturity $\leq 5$ & 73 & $6.05 \%$ \\
\hline $5<$ Maturity $\leq 10$ & 604 & $50.04 \%$ \\
\hline $10<$ Maturity $\leq 19$ & 184 & $15.24 \%$ \\
\hline Maturity $>19$ & 346 & $28.67 \%$ \\
\hline \multicolumn{3}{|c|}{ Panel C: Frequency Distribution of Debt IPOs by Years since Going Public } \\
\hline $0<$ Length $\leq 5$ & 279 & $23.12 \%$ \\
\hline $5<$ Length $\leq 10$ & 220 & $18.23 \%$ \\
\hline $10<$ Length $\leq 19$ & 253 & $20.96 \%$ \\
\hline Length $>19$ & 455 & $37.70 \%$ \\
\hline
\end{tabular}

\section{METHODOLOGY}

We first examine stock price reactions to debt IPO announcements using the standard event-study market model (Brown and Warner, 1985). day 0 is the Debt IPO announcement date. We estimate the market model for each issue over a 255 -day period ending on day -46 relative to the announcement date. We use the CRSP valueweighted index as the proxy for the stock market.

We calculate the daily abnormal return (AR) as:

$\mathrm{AR}_{i, t}=R_{i, t}-\left(\alpha_{i}+\beta_{i} * R_{\mathrm{M}, t}\right)$.

where $A R_{i, t}$ is the rate of abnormal stock return of issuing firm $i$ on day $t, R_{i, t}$ is the rate of stock return of issuing firm $i$ on day $t, R_{\mathrm{M}, t}$ is the rate of return of the market index on day $t ; \alpha_{i}$ and $\beta_{i}$ are the intercept and slope coefficient of stock i, respectively. The mean abnormal return (AAR) on day $t$ is defined as the average of abnormal stock returns across all issuing firms:

$\operatorname{AAR}_{f}=\frac{1}{N} \sum_{i=1}^{N} \mathrm{AR}_{i f}$

where $N$ is the total number of debt IPOs on event day t.

Following Mitchell and Stafford (1998) and Fama (1988), we compute the cumulative abnormal return $(C A R)$ to measure the stock price reaction to debt IPO announcements. Over an event window $\left[t_{1}, t_{2}\right]$, we calculate the cumulative average abnormal stock return for issuing firms as:

$C A R_{t 1, t 2}=\sum_{t=t 1}^{t 2} A A R_{t}$.

\section{EMPIRICAL RESULTS}

We report daily AARs and CARs along with their test statistics for the sample of debt IPOs in Panel A of Table 3. To fully capture the announcement effect and allow for possible information leakage prior to the announcement, we report AARs and CARs for an extended event window from day -30 to day +30 . The 61-day CAR amounts to -1.23 percent, which is statistically significant at $1 \%$ level, for the overall debt IPOs sample. The 
average abnormal return of debt IPOs on the announcement date is a significant -0.09 percent. The daily data reported in Panel A of Table 3 suggest that debt IPO issuers start to experience unfavorable risk-adjusted stock returns around a month preceding the announcement of their issues and such negative abnormal stock returns continue for another month following the announcements. Panel B of Table 3 reports negative and statistically significant cumulative abnormal returns (CAR) for selected event windows. For instance, the average CAR for the 3 -day $(-1,+1)$ window is -0.24 percent, and that for the 2 -day $(-1,0)$ window is -0.17 percent. These results echo those reported in Datta et al. (2000). Using a sample of 143 bond IPOs, they report a statistically significant negative abnormal stock return of -0.80 percent on the announcement date. Their 2-day and 3-day CARs are -0.86 percent and -0.99 percent, respectively.

Table 3

Panel A. Mean Abnormal Return and Cumulative Abnormal Return over $[-30,+30]$

This table reports the mean abnormal stock return (AAR) and the mean cumulative abnormal stock return (CAR) for 61 days surrounding the announcement of 1,207 corporate straight debt IPOs from 1970 to 2010. Day 0 is the announcement date of Debt IPO. The market model is used to estimate abnormal return with the model parameters estimated over the period day -300 to day -46. Z-Statistic tests the null hypothesis that the average abnormal return (AAR) is zero. For each event day, we also report the number of firms with positive AAR versus firms with negative AAR. *,**, and *** indicate statistical significance at the $10 \%$, $5 \%$, and $1 \%$ level, respectively.

\begin{tabular}{|c|c|c|c|c|c|c|c|c|c|}
\hline Day & $\mathbf{A} \mathbf{A} \mathbf{R}_{t}$, & $\begin{array}{l}\text { Positive: } \\
\text { Negative }\end{array}$ & $\begin{array}{c}\text { Z- } \\
\text { Statistic } \\
\end{array}$ & $\mathbf{C A R}_{t,}$ & Day & $\mathbf{A A R}_{t}$, & $\begin{array}{l}\text { Positive: } \\
\text { Negative }\end{array}$ & $\begin{array}{c}\text { Z- } \\
\text { Statistic } \\
\end{array}$ & $\mathbf{C A R}_{t}$, \\
\hline-30 & $-0.06 \%$ & $550: 657$ & -1.180 & $-0.06 \%$ & 1 & $-0.07 \%$ & $585: 622$ & -0.586 & $-0.90 \%$ \\
\hline-29 & $-0.06 \%$ & $544: 663$ & -0.568 & $-0.12 \%$ & 2 & $0.02 \%$ & $557: 649$ & 0.232 & $-0.88 \%$ \\
\hline-28 & $-0.07 \%$ & $556: 651$ & -0.563 & $-0.19 \%$ & 3 & $0.22 \%$ & $573: 633$ & -1.195 & $-0.66 \%$ \\
\hline-27 & $-0.01 \%$ & $581: 626$ & -0.780 & $-0.20 \%$ & 4 & $-0.03 \%$ & $553: 652$ & -0.721 & $-0.68 \%$ \\
\hline-26 & $0.07 \%$ & $584: 623$ & $1.315^{*}$ & $-0.13 \%$ & 5 & $0.06 \%$ & $570: 636$ & 0.366 & $-0.62 \%$ \\
\hline-25 & $0.03 \%$ & $569: 638$ & 0.746 & $-0.10 \%$ & 6 & $-0.11 \%$ & 544:662 & -1.181 & $-0.73 \%$ \\
\hline-24 & $0.12 \%$ & $596: 611$ & $1.723 * *$ & $0.02 \%$ & 7 & $-0.05 \%$ & $529: 676$ & -0.636 & $-0.79 \%$ \\
\hline-23 & $0.06 \%$ & $590: 617$ & 0.589 & $0.08 \%$ & 8 & $-0.11 \%$ & $551: 654$ & $-1.582 *$ & $-0.90 \%$ \\
\hline-22 & $-0.15 \%$ & $542: 665$ & $-1.985 * *$ & $-0.07 \%$ & 9 & $-0.11 \%$ & $538: 667$ & $-1.336 *$ & $-1.00 \%$ \\
\hline-21 & $-0.02 \%$ & $552: 655$ & -0.738 & $-0.08 \%$ & 10 & $0.09 \%$ & $581: 623$ & $1.354 *$ & $-0.91 \%$ \\
\hline-20 & $-0.05 \%$ & 579:628 & -0.016 & $-0.14 \%$ & 11 & $0.01 \%$ & $570: 635$ & 0.249 & $-0.91 \%$ \\
\hline-19 & $-0.07 \%$ & $544: 662$ & $-1.314 *$ & $-0.21 \%$ & 12 & $-0.04 \%$ & $572: 633$ & -0.309 & $-0.94 \%$ \\
\hline-18 & $-0.02 \%$ & $568: 639$ & -0.373 & $-0.23 \%$ & 13 & $-0.06 \%$ & $562: 642$ & -0.254 & $-1.00 \%$ \\
\hline-17 & $-0.04 \%$ & $547: 660$ & -0.990 & $-0.27 \%$ & 14 & $-0.03 \%$ & $569: 635$ & -0.719 & $-1.03 \%$ \\
\hline-16 & $0.10 \%$ & $571: 636$ & 1.054 & $-0.17 \%$ & 15 & $0.01 \%$ & $581: 623$ & 0.492 & $-1.02 \%$ \\
\hline-15 & $0.08 \%$ & 583:624 & 0.009 & $-0.09 \%$ & 16 & $-0.11 \%$ & $529: 675$ & $-1.710 * *$ & $-1.13 \%$ \\
\hline-14 & $-0.05 \%$ & $552: 655$ & -0.727 & $-0.14 \%$ & 17 & $-0.08 \%$ & $547: 657$ & $-1.339 *$ & $-1.21 \%$ \\
\hline-13 & $0.01 \%$ & $581: 626$ & 0.402 & $-0.13 \%$ & 18 & $-0.03 \%$ & $568: 636$ & 0.213 & $-1.23 \%$ \\
\hline-12 & $-0.05 \%$ & $565: 642$ & -0.715 & $-0.18 \%$ & 19 & $0.01 \%$ & $564: 640$ & -0.246 & $-1.23 \%$ \\
\hline-11 & $0.00 \%$ & $579: 628$ & 0.458 & $-0.18 \%$ & 20 & $0.05 \%$ & $586: 618$ & $1.326^{*}$ & $-1.18 \%$ \\
\hline-10 & $0.03 \%$ & 589:618 & 0.210 & $-0.15 \%$ & 21 & $-0.08 \%$ & 549:655 & $-1.526^{*}$ & $-1.26 \%$ \\
\hline-9 & $-0.06 \%$ & $554: 653$ & -0.638 & $-0.21 \%$ & 22 & $-0.04 \%$ & $559: 642$ & -0.255 & $-1.30 \%$ \\
\hline-8 & $0.07 \%$ & $603: 604$ & 1.085 & $-0.14 \%$ & 23 & $0.02 \%$ & $575: 625$ & 0.050 & $-1.28 \%$ \\
\hline-7 & $-0.10 \%$ & $545: 662$ & $-1.570 *$ & $-0.24 \%$ & 24 & $0.08 \%$ & $573: 628$ & 0.566 & $-1.20 \%$ \\
\hline-6 & $-0.13 \%$ & 533:674 & $-1.908 * *$ & $-0.37 \%$ & 25 & $0.00 \%$ & $570: 632$ & -0.349 & $-1.20 \%$ \\
\hline-5 & $-0.03 \%$ & $554: 652$ & -0.668 & $-0.40 \%$ & 26 & $0.04 \%$ & $554: 648$ & -0.498 & $-1.16 \%$ \\
\hline-4 & $-0.13 \%$ & $538: 667$ & $-1.519 *$ & $-0.53 \%$ & 27 & $0.02 \%$ & $558: 642$ & 0.438 & $-1.14 \%$ \\
\hline-3 & $-0.11 \%$ & $547: 659$ & -1.084 & $-0.64 \%$ & 28 & $-0.04 \%$ & $552: 649$ & -0.979 & $-1.18 \%$ \\
\hline-2 & $-0.02 \%$ & $575: 632$ & -0.276 & $-0.66 \%$ & 29 & $0.03 \%$ & $572: 629$ & -0.525 & $-1.15 \%$ \\
\hline-1 & $-0.09 \%$ & $553: 653$ & -1.080 & $-0.75 \%$ & 30 & $-0.08 \%$ & $562: 639$ & -1.067 & $-1.23 \%$ \\
\hline 0 & $-0.09 \%$ & $570: 637$ & $-1.739 * *$ & $-0.83 \%$ & & & & & \\
\hline
\end{tabular}

Panel B. Mean Cumulative Abnormal Returns for Selected Event Windows

This panel reports the mean cumulative abnormal stock returns (CAR), test statistics, and the number of firms with positive CAR and negative CAR for selected event windows for the Debt IPOs sample.

\begin{tabular}{cccc}
\hline Event Window & Mean Cumulative Abnormal Return & Positive: Negative & Z-Statistic \\
\hline$(-1,0)$ & $-0.17 \%$ & $530: 677$ & $-1.957^{* *}$ \\
$(-1,+1)$ & $-0.24 \%$ & $559: 648$ & $-1.906^{* *}$ \\
$(0,0)$ & $-0.09 \%$ & $570: 637$ & $-1.680^{* *}$ \\
\hline
\end{tabular}


In summary, our findings, in general, suggest that the market interprets the very first public offer of straight debt as a negative signal about the issuing firm. This finding is consistent with Miller and Rock (1985) that straight debt offer conveys negative information about possible earnings shortfall of the issuing firm. However, the smaller magnitude of the negative valuation effect of debt IPOs than that of seasoned equity offers is consistent with the prediction of the adverse selection model of Majluf and Myers (1984).

\section{Bond Ratings and Economic Conditions}

Kisgen (2006, p.1039) argue that "Rating agencies may receive significant company information that is not public. For instance, firms may be reluctant to release information to the market that would compromise their strategic programs, in particular with regard to competitors. Credit agencies might also specialize in the information gathering and evaluation process and thereby provide more reliable measures of a firm's creditworthiness." In their capital screening model, Millon and Thakor (1985) show that credit rating agencies could use their privileged information to screen the quality of issuing firms and reflect it in their rating of the issue.

For high quality (low risk) straight debt, their contractual payments are reasonably predictable under the protection of bankruptcy law. However, low grade (high risk) corporate bonds are considered to have a larger equity component with cash flow and risk characteristics similar to those of equity (Shane, 1993; Datta et al., 1997).

The adverse selection model of Myers and Majluf (1984) predicts that stock price reaction to the announcement of IG debt IPOs would be more favorable than that for HY issues. On the other hand, Miller and Rock (1985) suggest no difference in the negative valuation effect of debt IPOs regardless of the riskiness of the issue. In Figure 1a, we plot the CAR over the 61-day $(-30,+30)$ window for the overall debt IPO sample, as well as the IG and the HY subsamples. Consistent with the prediction of the adverse selection model, Figure 1a shows a distinctive CAR patterns between the two subsamples of debt IPOs. The 61-day cumulative abnormal return is a significant -3.27 percent for HY debt IPO issuers, compared to an insignificant 0.19 percent for IG debt IPO issuers. It is apparent that the significant negative CAR for the overall sample is driven by the risky low quality issuers.

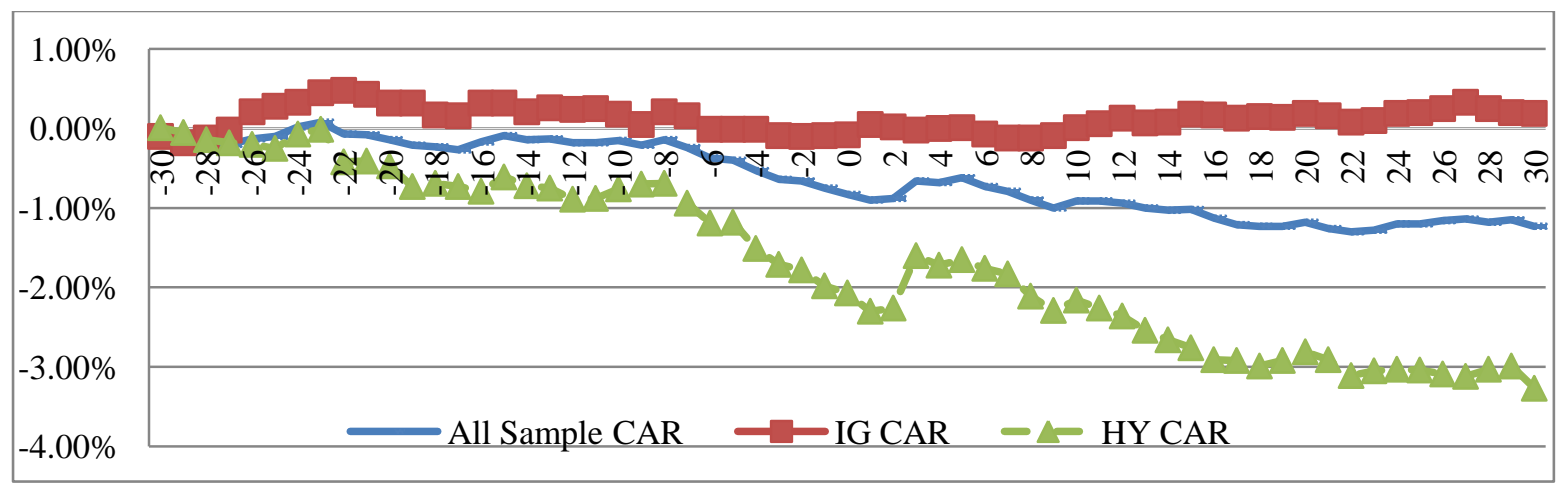

Figure 1a. Cumulative Abnormal Returns $[-30,+30]$

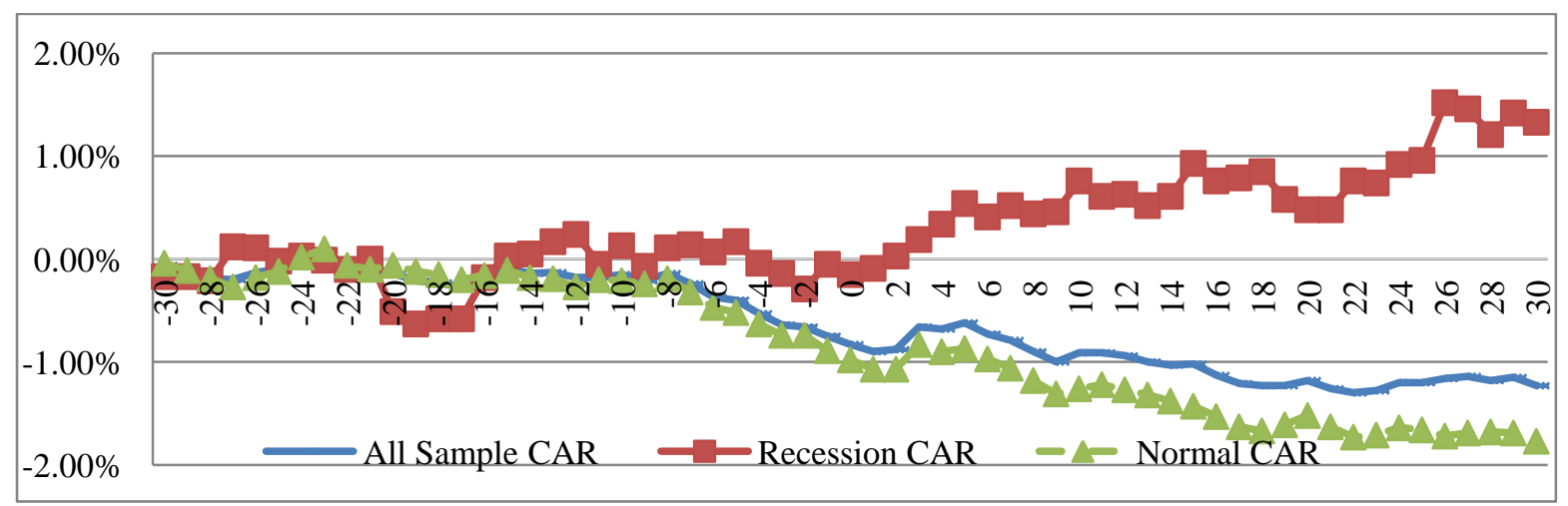

Figure 1b. Cumulative Abnormal Returns $[-30,+30]$ 
Bernanke and Gertler (1989) formalize practitioners' claim that poor economic conditions could further prohibit the access of low quality issuers to public debt market. As such, successful debt issues during economic downturns could be considered as a favorable indication of the quality of issuing firm. Jilio, et al. (2008) provides supportive evidence that macroeconomic conditions affect the quality distribution of seasoned debt securities being offered. They document fewer low quality debt issued during recessions, while there are comparable numbers of high quality bond issues and low quality bond issues during good times. The economic condition screening argument suggests that IG debt IPOs would dominate the market in economic recessions. Building on the prediction of a more favorable stock price reaction to less risky, higher quality debt issue (Myers and Majlur, 1984), we thus postulate that more favorable stock price reactions are associated with debt IPOs that are issued during economic downturns than those that are issued in good times.

To examine the possible impact of economic conditions on the valuation effect of debt IPOs on stock returns, we categorize sample debt IPOs by overall business environment according to the determination of the NBER for precise dates of a recession's onset and end. We find about one-sixth of our debt IPOs were announced during economic recessions.

In Figure 1b, we plot the CAR over the 61-day $(-30,+30)$ window for the overall sample period, as well as the recession period and the normal period subsamples. Consistent with the implication of Bernanke and Gertler (1989), Figure 1b shows a distinctive CAR patterns between the two subsamples of debt IPOs. The 61-day cumulative abnormal return for debt IPOs issued during economic downturns is a significant positive 1.33 percent, compared to a significant negative -1.69 percent CAR for debt IPOs issued in a favorable economic environment.

We further examine the possible roles of bond ratings and economic conditions in explaining the valuation effect of debt IPOs on stock returns by comparing the 3-day $(-1,+1)$ CAR of IG issues versus HY grade issues in normal and recession states of economy. The results reported in Table 4 show a disproportionate share of IG issues dominating $\mathrm{HY}$ issues at a ratio of three to one among successful debt IPOs during economic downturns. There are 93 IG bonds, which account for over $18 \%$ of all high quality debt IPOs, compared to $31 \mathrm{HY}$ bonds that account for around $7 \%$ of all risky debt IPOs, issued during recessions. On the other hand, the number and proportion of IG bonds (408 and 81\%) issued in normal economic condition are comparable to those of the HY bonds (425 and 93\%).

Table 4. Mean Cumulative Abnormal Returns [-1, +1] for Different Sub Samples

This table reports the comparison of mean cumulative abnormal returns (CAR) for sample firms that issue investment grade (IG) bonds versus sample firms that issue high-yield (HY) bonds between 1970 and 2000 in the recession period and the normal period. Day 0 is the announcement date of debt IPOs. The market model is used to estimate abnormal return with the model parameters estimated over the period day -300 to day -46 . T-statistic tests the null hypothesis that the mean cumulative abnormal return (CAR) is the same between two samples. *,**, and *** indicate statistical significance at the $10 \%, 5 \%$, and $1 \%$ level, respectively.

\begin{tabular}{l|ccc|ccc|cc}
\hline & \multicolumn{3}{|c|}{ Investment Grade } & \multicolumn{3}{c|}{ High-Yield Grade } & \multicolumn{2}{c}{ Difference } \\
\hline & $\mathbf{N}$ & $\boldsymbol{\%}$ & Mean CAR & $\mathbf{N}$ & $\mathbf{\%}$ & Mean CAR & Difference & T-statistic \\
\hline Normal & 408 & $81.44 \%$ & $-0.03 \%$ & 425 & $93.20 \%$ & $-0.62 \% * *$ & $\mathbf{0 . 5 9 \%} \% *$ & 2.01 \\
Recession & 93 & $18.56 \%$ & $0.92 \% *$ & 31 & $6.80 \%$ & $0.83 \%$ & $\mathbf{0 . 0 9 \%}$ & 0.07 \\
Total & 501 & $100.00 \%$ & $0.15 \%$ & 456 & $100.00 \%$ & $-0.52 \% * *$ & $\mathbf{0 . 6 7 \%} \% *$ & 2.13 \\
\hline
\end{tabular}

In parallel with the CAR patterns presented in Figures 1a and 1b, debt IPO issues that are rated as IG experience more favorable stock price reaction than HY issues, especially during the normal economic conditions where the difference in CARs between the two groups is statistically significant at 5\% level. It is interesting to note that debt IPOs of both investment grade and high-yield samples experience positive CAR during economic downturns. This result is consistent with the postulation that only quality issuers will be successful in accessing public debt market during poor economic conditions. Overall, the findings that high quality (low risk) debt IPOs experience a more positive or less negative stock price reaction than their low quality (riskier) debt IPO counterparts are consistent with the adverse selection model of Myers and Majluf (1984), but not the earnings shortfall explanation of Miller and Rock (1985). 


\section{Multivariate Regression Analysis}

We report the ordinary least squares regression results in Table 5. The dependent variable of the multivariate regressions is $\mathrm{CAR}_{-l,+1}$, which is the cumulative abnormal stock return of the issuing firm over the three-day announcement period of its debt IPO.

Table 5. Ordinary Least Squares Regressions

This table reports the regression results on the announcement period cumulative abnormal stock returns for Debt IPOs that have at-issue bond ratings. The Dependent variable is $C A R_{-1,+1} I G$ is the investment grade dummy that takes a value of one if the bond is rated BBB or higher, and zero otherwise. NYSE is a dummy variable that takes a value of one if the issuing firm is listed on the New York Stock Exchange, and zero otherwise. Maturity is the natural log of the term of maturity (in years) of the Debt IPO issue. Proceed is the natural log of the Debt IPO's offer size in millions in constant 2000 dollar. Length is the natural log of the years since the Debt IPO issuing firm went public. Recession is a dummy variable that takes a value of one if the Debt IPO is in a NBER recession period, and zero otherwise. IG_Recession is the interaction of the IG and Recession dummy variables. It takes a value of one if the Debt IPO issue is rated investment grade and offered in a NBER recession period, and zero otherwise. Baa_ret is the cumulative return on Baa-rated bonds for the three months leading to the Debt IPO announcement. VW_ret is the cumulative return on CRSP value-weighted stock index for the three months leading to the Debt IPO announcement.*, **, and *** indicate statistical significance at the $10 \%, 5 \%$, and $1 \%$ level, respectively.

\begin{tabular}{lcccccc}
\hline & \multicolumn{2}{c}{ Model 1 } & \multicolumn{2}{c}{ Model 2 } & \multicolumn{2}{c}{ Model 3 } \\
\cline { 2 - 7 } \multicolumn{1}{c}{ Variables } & Coefficient & T- value & Coefficient & T- value & Coefficient & T- value \\
\hline Intercept & 0.77 & 0.64 & 1.24 & 0.86 & 1.22 & 0.84 \\
IG & $0.82^{* *}$ & 2.26 & $0.73^{* *}$ & 1.99 & $0.78^{* *}$ & 2.06 \\
NYSE & 0.31 & 0.91 & 0.29 & 0.84 & 0.29 & 0.83 \\
Maturity & -0.10 & -0.32 & -0.06 & -0.18 & -0.06 & -0.20 \\
Proceed & -0.17 & -1.09 & -0.22 & -1.32 & -0.22 & -1.31 \\
Length & -0.18 & -1.27 & -0.20 & -1.45 & -0.20 & -1.46 \\
Recession & & & $1.26^{* *}$ & 2.58 & $1.65^{*}$ & 1.83 \\
IG_Recession & & & & & -0.55 & -0.52 \\
Baa_ret & & & -3.48 & -0.48 & -3.44 & -0.48 \\
VW_ret & & & -1.79 & -0.60 & -1.89 & -0.64 \\
\hline
\end{tabular}

We include the following bond characteristics variables in regression models: $I G$ is the investment grade dummy that takes a value of one if the bond is rated BBB or higher, and zero otherwise. NYSE is a dummy variable that takes a value of one if the issuing firm is listed on the New York Stock Exchange, and zero otherwise. Maturity is the natural $\log$ of the term to maturity (in years) of the debt IPO issue. Proceed is the natural log of the debt IPO's offer size in millions in constant 2000 dollars. Length is the natural $\log$ of the years since the debt IPO issuing firm went public.

The results from Model 1 show that only the investment grade dummy $(I G)$ explains the variation in the valuation effect of debt IPO announcement. The statistically significant (at the 5\% level) positive coefficient of the $I G$ dummy indicates that these high quality (low risk) issuers enjoy a $0.82 \%$ premium in risk-adjusted cumulative stock return over the three-day period surrounding their debt IPO announcements, when compared to their riskier peers that have low bond ratings. Consistent with the adverse selection model of Myers and Majluf (1984), the certification effect of an investment grade rating helps separate low risk issuing firm from their riskier peers that lead to favorable stock price reactions to their financing decisions in an information asymmetry setting.

Prior studies document that recent return performance in the stock and bond markets could impact the valuation effect of seasoned security offering on stock returns of issuing firms (Eckbo et al., 2007). Hence, in Model 2, we include the $V W \_R e t$ and $B a a_{-}$ret variables to control for the possible impacts of bond and stock market conditions on the announcement period CAR of debt IPOs. Baa_ret is the cumulative return on Baa-rated bonds for the three months leading to the debt IPO announcement. $V W_{-}$ret is the cumulative return on CRSP value-weighted stock index for the three months leading to the debt IPO announcement.

In the preceding section, we find that the economic condition around debt IPO has a material impact on the stock price reaction. Hence, in Model 2, we also include a dummy variable Recession, which takes a value of 1 if the Debt IPO is announced in a NBER recession period, and 0 otherwise to capture the economic condition effect. 
Results from Model 2 echo those from Model 1. The significant positive impact of investment grade rating on the valuation effect of debt IPO announcement persists after controlling for economic and financial market conditions. The positive and significant coefficient of the Recession dummy, which indicates that debt IPOs issued during economic downturns are received more favorably by the markets than those issued in normal economic environment. This result confirms the univariate results concerning the impacts of bond ratings and economic conditions on the valuation effect of debt IPOs on stock returns reported in Table 4.

The univariate results also show a distinctive distribution of investment grade and high-yield issues during economic downturns versus normal economic condition. In particular, high quality bonds (IG rating) dominate highyield issues in economic recessions. In attempt to distinguish the bond rating effect from the economic condition effect, in Model 3, we add an interaction variable, IG_Recession, which is the interaction of the $I G$ and Recession dummy variables. It takes a value of one if the debt IPO issue is rated IG and announced in a NBER recession period, and zero otherwise. The results in Model 3 confirm the univariate results reported in Table 4. The coefficient of the IG_Recession dummy is insignificantly negative. This implies that during recessions, the quality of bond issues does not have a material impact on the stock price reactions to debt IPO announcements. The result is consistent with the implication of Bernanke and Gertler (1989) that the market recognizes and rewards quality issuers who successfully conduct debt IPOs even during challenging economic times. The significant positive coefficient of the Recession dummy persists in Model 3, suggesting that the primary source of difference in the CAR between IG and HY debt IPOs is driven by bonds that are successfully issued in normal time.

Overall, the results of the multivariate regression analysis support the implication of the adverse selection model that the less risky the issue and the higher quality the issuer, the less adverse valuation effect is the debt IPO announcement on stock return of the issuing firm. In addition to the bond rating that serves as a certification of issuer quality, the market also favorably perceives successful issues during economic downturns and reacts accordingly to their debt IPO announcements.

\section{CONCLUSION}

We examine the valuation effect of initial public debt offers on common stock of issuing firms for an extended period of 1970 to 2010 . We find a statistically significant negative risk-adjusted cumulative abnormal return of -0.24 percent over the three-day announcement period for the overall sample of 1,207 debt IPOs. Further results, however, indicate distinctive valuation effects are associated with the quality of the issues and the economic conditions under which the debt IPOs take place. Consistent with the prediction of the adverse selection model of Myers and Majluf (1984), the significant negative valuation effect of debt IPOs is only associated with risky issues that are assigned a high-yield bond rating. In contrast, the market receives the announcements of low-risk investment grade debt IPO issues with an insignificant positive stock price reaction. In addition to the certifying effect of investment grade rating, the market also reacts favorably to successful debt IPOs issued under challenging conditions. Consistent with the implications of Bernanke and Gertler (1989), we find a positive valuation effect for debt IPOs issued during economic recessions despite their bond ratings. While an initial public debt offer allows the issuing firm valuable access to the enormous bond market for funding needs, the costs of issuance could be substantial. It is critical for quality issuers to distinguish themselves from their peers with the assistance of certifying agents in order to contain the issuance costs of their initial debt public offer.

\section{AUTHOR INFORMATION}

Kelly Nianyun Cai is an associate professor at University of Michigan - Dearborn. Her research covers a variety of topics, including initial public offerings (IPOs), bond pricing and capital market. Her research has been published in refereed journals such as Review of Financial Studies, Financial Management, The Financial Review, Journal of Fixed Income, Journal of Financial Research and Journal of Business Research. E-mail: kcai@umd.umich.edu (Corresponding author)

Hei-Wai Lee (Ph.D., The University of Illinois at Urbana-Champaign) is a Professor of Finance at The University of Michigan-Dearborn. His current research interests include seasoned security issuance and IPOs, information content of analysts' coverage, cross-listing of foreign firms, insider trading, managerial compensation, and capital 
market research. He has published over 30 articles in Financial Management, Financial Review, Journal of Business Finance and Accounting, Journal of Business Research, Journal of Financial Research, and Journal of Applied Business Research, etc. His research has received several best paper awards at the professional conferences. E-mail: heiwail@umd.umich.edu

\section{REFERENCES}

1. Bernanke, B., and M. Gertler (1989). Agency Costs, Net Worth, and Business Fluctuations, American Economic Review, 79 (March), 14-31.

2. Brown, S. J., and J. B. Warner (1985). Using Daily Stock Returns: The Case of Event Studies. Journal of Financial Economics, 14, 3-31.

3. Datta, S., M. Iskandar-Datta, and A. Patel (1997). The pricing of initial public offers of corporate straight debt. Journal of Finance, 52, 379-396

4. Datta, S., M. Iskandar-Datta, and A. Patel (2000). Some Evidence on the Uniqueness of Initial Public Debt Offerings. Journal of Finance 55, 715-743

5. Eckbo, B.E(2007). Handbook of Corporate Finance. Retrieved from: http://store.elsevier.com/Handbookof-Corporate-Finance/isbn-9780444508980/

6. Fama, E. F. (1998). Market Efficiency, Long-Term Returns, and Behavioral Finance. Journal of Financial Economics, 49, 283-306

7. Hale, G and J. Santos (2008). The Decision to First Enter the Public Bond Market: The Role of Firm Reputation, Funding Choices, \& Bank relationships. Journal of Banking and Finance 32, 1928-40.

8. Julio, B., K. Woojin and W. Michael S (2008). What Determines the Structure of Corporate Debt Issues? Retrieved from: http://ssrn.com/abstract=1093302

9. Kisgen, D. (2006). Credit Ratings and Capital Structure. Journal of Finance, 61(3), 1035-1072

10. Miller, M. H., and K. Rock (1985). Dividend Policy under Asymmetric Information. Journal of Finance, 40, 1031-1052.

11. Millon, M., and A. Thakor (1985). Moral hazard and information sharing: A model of financial information gathering agencies. Journal of Finance, 40, 1403-1422.

12. Mitchell, M. L. and E. Stafford (1998). Managerial Decisions and Long-Term Stock Price Performance. Unpublished Working Paper, University of Chicago Business School

13. Myers, S.C. (1984). The capital structure puzzle. Journal of Finance, 39, 575-592.

14. Myers, S.C. and N. Majluf (1984). Corporate financing and investment decisions when firms have information investors do not have. Journal of Financial Economics, 13, 187-221.

15. Shalen, C.T. (1993).Volume, Volatility, and the Dispersion of Beliefs. Review of Financial Studies, 6, 405434.

16. Shyam-Sunder, L. (1991). The stock price effect of risky versus safe debt. Journal of Financial and Quantitative Analysis, 26, 549-558.

17. Smith, C. W. (1986). Investment Banking and the Capital Acquisition Process. Journal of Financial Economics, 15, 3-29. 